\title{
The Struggle to Love. Pedagogical Eros and the Gift of Transformation
}

\begin{abstract}
Why does anyone become a teacher, and why a student? Education in its contemporary form has evolved into a subsystem of society in which professional 'teachers/ educators' are confronted with an ever-changing group of people called 'pupils/ students'; and the individuals in both groups now have to deal with this institutionalized confrontation. Neither one nor the other decision - to become a teacher or to become a student - seems to have much to do with a specific other person, and it certainly does not have much to do with the actual person(s) that one is related to by becoming a teacher or by becoming a student in a specific institution. However, if pedagogical relations were as depersonalized as suggested, why is it that teachers as well as students would hold very different relations to different students and teachers - relations that are more or less 'deep', 'affectionate', 'successful'? And how are we to perceive education outside of formally institutionalized contexts (or those special relations that occur even within formalized contexts but transcend them)? Is there another type of pedagogical relation? And what would be reasons for entering into a pedagogical relation other than becoming and being made a part of a subsystem of society? Why do two people gravitate towards each other, freely recognizing each other as teacher and student? Attempting to answer those questions, the following paper revisits some historic positions, being conscious that those answers are also part of the answer to a much greater question: What is education?
\end{abstract}

Keywords: History of Education; Philosophy of Education; Comparative Education; Pedagogical Relation; Platonic Love; Pedagogy

\section{Relations, or The Emergence of Teacher and Student}

Why does anyone become a teacher, and why a student? Education in its contemporary form has evolved into a subsystem of society whose main purpose seems to be to offer qualifications and degrees in order to enable an effective use of human capital by finding the right person for the right job. Occasionally this is expanded by including the idea that somehow education also serves as a tool to form the growing youngsters into beings who at least do not interrupt the ways of society and maybe even fortify them through re-enactment (Biesta, 2009). ${ }^{1}$ Looking at education in this way, the reasons for becoming a teacher are numerous, but often related to the advantages that the teacher-profession offers: the possibility to work within a subject field that is of personal interest ${ }^{2}$, a usually stable and fairly acceptable salary that comes with a comparatively high level of social recognition and a comforting certainty (or illusion?) of being able to help and support others in their development ${ }^{3}$; to become a student then is rarely an act of choice but the result of being a part of a machinery that one is sucked into through upbringing, compulsory schooling and a more or less neo-liberal agenda of so- 
called 'life-long learning' ${ }^{4}$ - a process which eventually justifies itself by teaching that it is exactly this type of education that allows for the fulfillment of all individual dreams - or, to use some slightly altered words of Ivan Illich: "School is the advertising agency which makes you believe that you need the school as it is." ${ }^{\prime 5}$

Neither one nor the other decision - to become a teacher or to become a student - seems to have much to do with a specific other person (which is, given the emphasis on institutionalized forms of education as expressed in the perceivable relevance of official degrees, not surprising), and it certainly does not have much to do with the actual person(s) that one is related to by becoming a teacher or by becoming a student in a specific institution: The teachers are teachers before they meet their individual students, the students are students before they meet their individual teachers. Even where student teachers' decision to become a teacher is driven by some sort of altruism (e.g. to help children grow and develop) this decision is largely governed more by general concepts of children and childhood (or learners) and general ideas about the relation of child (or learner) and society than by the encounter with a particular other. In modern education, it seems the relation of teacher and student has been depersonalized; those positions have been structurally defined on an institutional level. What would be (and maybe used to be) central to being a teacher and being a student - namely: being in a pedagogical relation to a specific person (Friesen, 2017) - has in its institutionalized form been transformed into being part of an arrangement in which the establishment of personal relations is, if at all, of only secondary importance (and, more often than not, isn't successful at all). The pedagogical relation here is very much an instrumental one: their roles being institutionally prescribed, teachers use 'their' students to provide the necessary ignorant material upon which they can exercise their pedagogical power in order to gain all the advantages that come with their status as being teachers; whereas students use 'their' teachers as providers of the kind of knowledge they have been trained and manipulated (or: educated) to believe to be of advantage for them.

However, some may feel that something is missing from this picture. If pedagogical relations were as depersonalized as suggested, why is it that teachers as well as students would hold very different relations to different students and teachers - relations that are more or less 'deep', 'affectionate', 'successful'? Moreover, as has been acknowledged, it is the character of the pedagogical relation that 
usually determines the relation students have to individual school subjects, and not the other way around. Which means: Even though formally the pedagogical relation is established through institutionalized structures without regard to individual persons, it is the personality of the involved individuals that possibly changes the pedagogical relation - a change that occurs only sometimes and maybe even only very rarely, and that is in no way necessary for this relation to be called a 'pedagogical' relation despite it's sometimes being sought after especially in the education of younger children (but here, too, often for mere instrumental reasons). Even if we don't allow ourselves to call those somewhat 'enhanced' pedagogical relationships instances of 'true' pedagogical relations in comparison to the other, maybe a little 'inferior' sort of relationships, there definitely is a different quality to them (a quality that for example has the power to change the emotional relation a student has to a specific school subject but often is not limited solely to this effect).

Realizing those different characters of pedagogical relations, one could ask for the foundations of such differences. And since much of what has been described above is related to a modern kind of institutionalized education where roles are prescribed through commonly shared ideas of positions and institutionalized 'profession' and status rather than being based upon self-negotiation, it can and should be asked what those pedagogical relations are founded upon which are not established through definitions of social roles but through the encounter of individuals; how are we to perceive education outside of formally institutionalized contexts (or those special relations that occur even within formalized contexts but transcend them)? Is there another type of pedagogical relation? If there is - and of course: the question posed in this way is only a rhetorical one -, there also would need to be reasons for entering into a pedagogical relation other than becoming and being made a part of a subsystem of society. Why do two people gravitate towards each other, freely recognizing ${ }^{6}$ each other as teacher and student; what turns a purely formal pedagogical relation based on roles into something based upon the individualities and personalities of those relating to each other?

As so often, it is history that provides us with models which could serve as the necessary standpoint of criticism or offer alternatives (intercultural comparison could of course be just as enlightening). Where exactly one looks is somewhat arbitrary, but looking at the other is the point: It is precisely the puzzling strangeness of the other that is capable of broadening the individual horizon of the investigator. ${ }^{7}$ So 
let's have a look back into what happened in Germany at the beginning of the $20^{\text {th }}$ century, to be pushed back from there even further to Plato and his Symposium, only to fly back to our time on the wings of Eros, armed with love's bow and arrow to accept the challenge to stand up against the maybe deeply un-erotic nature of contemporary education. As will be seen: the argument takes on the form of a spiral as we will begin in early $20^{\text {th }}$ century Germany, just to then venture to Plato, and to return in our times.

\section{Passions, or The Critique of Instrumentalism}

The history would start in the 1870s in Germany when a young scholar called for the youth to stand up against the older generation, when he criticized the educational ideal for being empty and bloodless and the society as a whole for becoming more and more industrious and mechanical, governed by mediocracy and resentment, where both, the individuals and the community lacked the necessary ecstasy to being truly alive or even great (Nietzsche, 1872; 1874). Nietzsche was, of course, not the only one who criticized the culture in this way, ${ }^{8}$ and it was this type of critique that gave rise to new idols: the Lebensreformbewegung (life reform movement) propagated a back-to-nature lifestyle, emphasizing among other things healthy/ raw/ organic food, nudism, sexual liberation, alternative medicine, and religious reform and at the same time abstention from alcohol, tobacco, drugs, and vaccines - a movement that found its visual expression in what became famous as German Jugendstil (art nouveau) with its slender, naked girls and boys gracefully and ecstatically dancing through the meadows, worshipping the sun, and that found its equivalent in the centrality the notion of Leben (life) suddenly acquired within the sciences and humanities ${ }^{9}$ of that era. And it was this movement that provided the foundation for what then became the German Progressive Education movement (in German: Reformpädagogik $)^{10}$ - a range of different pedagogies that not only shared a vision of a childcentred $^{11}$ pedagogy, but also a vision of a deeply personal relation between teacher and student $-\mathrm{a}$ relation that is born out of a very conscious act of two people submitting to a relation. ${ }^{12}$ It was not a socalled 'educational' institution that transformed people into teachers or students by merely entering it: the pedagogical relation was perceived as being founded upon a drive of the people involved - a drive that made people gravitate towards each other, a drive for which the old term 'Pedagogical Eros' was re-introduced. In doing so, the pedagogues related themselves to the long history of this concept which, 
since its introduction in Plato's Symposium, has been perpetuated in several (especially neo-platonic) texts throughout history. ${ }^{13}$

By no means were the Eros-concepts of, for example, Eduard Spranger, Gustav Wyneken, Kurt Zeidler and Herman Nohl identical. What they shared, however, was an idea of the pedagogical relation as being based upon a passionate mutual attraction of two similar souls, where one would freely submit to the authority of the other who in turn acts as a guiding friend and comrade, as lover even. How deepreaching this relation was thought to be, might become clear in the words of Zeidler who states that only that person who is governed

by the Great Understanding, the love that dissolves completely in the essence of the young person, who grants total affirmation to all his flaws and weaknesses, all his imperfections and uncertainties, who never ceases to trust and never stops to believe into the Divine power of the young soul (Zeidler, 1920: 4; transl. K.K.)

could become a teacher. Nohl elaborates:

The foundation of Education therefore is the passionate relation of a mature person to a growing youth for the youngster's own sake so that the young eventually finds to her own life and form. (Nohl/ Pallat, 1933: 22; transl. K.K.)

As can be seen: the pedagogical relation is one based on passionate love and mutual affirmation, a love that does not use the other as means to an end, but where the teacher is attracted by what he sees in the individual student as potential of a new and complete life and where the student is attracted to the individual teacher as he seeks for safety and guidance, for love and recognition in his or her will to grow and develop (Nohl/ Pallat, 1933: 24; transl. K.K.). Both sides of the relation are driven into this relationship not by the attempt to become more similar to each other: the teacher does not want to fill the student with his/her content, with his/her form, with his/her ideas, and the student does not attempt to copy the teacher but accepts the teacher as a guiding image in her/his wholeness and maturity in general but not in particular.

What all those theories have in common is that they all refer to Plato and the concept of the Pedagogical Eros $^{14}$ as introduced in the Symposium (199c-212c). As this is widely known, no in-depth analysis of 
Plato's theory is necessary here. But it should be immediately obvious that the reference to Plato introduced some difficulties for the Germans: Platonic Pedagogical Eros is originally not categorically distinguished from what we might call sexual eros - it even allows for carnal desires and corporeal entanglements to be the first steps on the ladder up to the Idea of the Good, hereby providing the necessary answer to the question as to why a specific person is attracted to another specific person. The modern German theorists found it necessary to exorcise themselves from those sexual aspects by attempting to distinguish between pedagogical eros and sexual eros. This became even the more urgent the more it became clear that this was not just about sexuality but about same-sex desire in particular. ${ }^{15}$ Most of those theorists were either part of, or strongly influenced by, the contemporary German youth movement, which was characterised by heated debates about the relation of the sexes/ genders and the meaning of the manifest same-sex-desires or mutual attraction between youngsters of the same sex (Geuter, 1994). It was under those conditions of an increasing attention paid to the sexual and emotional development of young people that the phase of adolescence as a phase mainly characterised by sexual uncertainties and experiments was invented. ${ }^{16}$ More or less helplessly, the German pedagogues repeated the distinction between the corporeal and the spiritual introduced by Plato, by either stating that the sexual drive is the foundation from which teacher and student have disconnected themselves completely through sublimation, or by assuming it to be a completely different drive altogether (disentangling themselves from Plato here). Whatever path was chosen: In order to keep the pedagogical eros pure from carnal pollution, sexual eros was turned into something animalistic that was just a corporeal means to a reproductive end - a tool that could not have a part in the self-less relation established on the grounds of pedagogical eros.

However, this emphasising of the self-less-ness, of the pedagogical relation as being based upon the will of not using the other as a means to an end, brings us back to Plato and to the original concept of the pedagogical eros. How self-less was it really with Plato?

\section{Lovers, or The Enigma of Attraction}

It might not be necessary here to recapitulate Plato's theory of Eros in its totality. Just as a little reminder: Eros is a desire founded upon the absence of something: 
Then such a person, and in general all who feel desire, feel it for what is not provided or present; for something they have not or are not or lack and that sort of thing is the object of desire and love[.] (Symposium 200e)

That, however, is not the only condition for the pedagogical relation to be established, as Diotima points out:

All men are pregnant, Socrates, both in body and in soul: on reaching a certain age our nature yearns to beget. This it cannot do upon an ugly person, but only on the beautiful: the conjunction of man and woman is a begetting for both. (Symposium 206c)

The reason for this yearning is explained in relation to human mortality:

$[\mathrm{T}]$ he mortal nature ever seeks, as best it can, to be immortal. In one way only can it succeed, and that is by generation; since so it can always leave behind it a new creature in place of the old. (Symposium 207d)

This does, however, not mean that the offspring that guarantees immortality is an exact copy of the ancestor:

Every mortal thing is preserved in this way; not by keeping it exactly the same for ever, like the divine, but by replacing what goes off or is antiquated with something fresh, in the semblance of the original. Through this device, Socrates, a mortal thing partakes of immortality, both in its body and in all other respects; by no other means can it be done. So do not wonder if everything naturally values its own offshoot; since all are beset by this eagerness and this love with a view to immortality. (Symposium 208a-b)

Those are the anthropological foundations of the pedagogical relation as introduced by Plato: One person strives for immortality and therefore needs to procreate (and whereas women can rely on corporeal, i.e. material procreation, men need to resort to spiritual procreation - a difference that turned misogynistic through the uprating of the spiritual in comparison to the material); and since this impregnation can only occur in something beautiful, the spirit of an old man is drawn to the beautiful young boys to sow his seeds: It is the corporeal beauty of the youth that the old man lacks and therefore 
is gravitating towards. But this is only the beginning: Even though this process starts based on a desire for a specific individual boy and his particular perceivable beauty, somehow the older starts to see the beauty in all bodies (which means: one becomes able to relate in a very corporeal sense to basically every other person), just to then discover that what attracts even more is the beauty of firstly one soul, then the beauty of all souls, and finally beauty in itself, i.e. the idea of beauty, where we end up in the regions of the idea of the good or the idea of ideas. Even through this only short re-collection of Plato's theory it might become clear that we basically look solely upon the urges of what eventually becomes the teacher in the process: it is his (and Plato solely talks about men) desire that gradually leads him to finally comprehend the idea of ideas. The student does not seem to play a role here except providing the means through which the teacher rises up (or is the student already on a higher level as he solely desires the teacher for his soul? ... That would introduce an interesting paradox ...). Moreover: it remains relatively unclear whether or not the teacher uses the student as a means to the end of rising and enlightenment, or if all that just simply happens unplanned, unwanted, involuntarily, which would position the student as providing the ladder but not being a tool that is consciously used by the teacher. And why does actually the student choose this specific person as a teacher? In Plato's horizon, this cannot be because the teacher is such a beauty ${ }^{17}$. So is therefore the teacher only picked because he promises some sort of knowledge (the lack of which makes the student gravitate towards the wise older), which would then turn the teacher into a tool that is used by the student? An explanation whose apparent plausibility becomes somewhat blurry if it is remembered that the teacher, Socrates, keeps denying to have any knowledge at all (and, indeed, never claims to have entered the highest sphere of knowledge: he never grasped the idea of ideas). Or are we looking at two altogether different pedagogical relations: one, where teacher and student relate to each other very consciously to profit from each other in terms of knowledge and wisdom transfer on the student's side, and on the teacher's side in terms of assuaging his desires for immortality, beauty and embraces (which might have been the normal arrangement in what became famous as the institution of pederasty (Dover, 2016)) - hereby enacting unconsciously a second pedagogical relation through which the teacher rises up towards comprehension of the idea of ideas? Diotima states surprisingly little about the motivation of the student and its relation to the ascension of the teacher towards the idea of ideas: Even though the lack of wisdom might be counted 
as a general explanation for the attraction a young boy feels towards an older man, there are no further claims being made with regard to any sort of up-rising of the student.

A next move takes us from Diotima's speech that leaves us with all those uncertainties to the actual relationship of Pedagogical Eros that is described in the Symposium - a relation described from the perspective of the younger student towards the older teacher - the relationship of Alcibiades and Socrates. Why does Alcibiades love Socrates, and, subsequently: why did Alcibiades accept Socrates as teacher, why was he drawn to him? Was it because Socrates was so wise, knew so much, or was so beautiful? None of those:

Nestor, Antenor, or others I might mention, with Pericles; and in the same order you may liken most great men; but with the odd qualities of this person, both in himself and in his conversation, you would not come anywhere near finding a comparison if you searched either among men of our day or among those of the past [.] (Symposium 221d)

Not only here, but in other dialogues, too ${ }^{18}$, Socrates is described as atopos, as strange, out-of-place, incomparable and therefore enchanting and entrancing. ${ }^{19}$

For he brings home to me that I cannot disown the duty of doing what he bids me, but that as soon as I turn from his company I fall a victim to the favors of the crowd. (Symposium 216b)

In a somewhat mysterious way, the atopos Socrates disconnects Alcibiades from his usual state of being, or, in words that echo Levinas: It's the Otherness of the Other which we are looking for in the Other (Levinas, 1987). Here we finally see why Alcibiades falls for Socrates and therefore why he pursues the establishment of a relation to Socrates that then is to be called a pedagogical relation: he cannot help it. Even though the encounter with Socrates is disruptive, a negative force with regard to Alcibidades' normal ways of being, he still embraces this kind of disturbance and alienation. It is not a conscious decision to be attracted to someone, and it certainly is not the thought of using someone as a means to an end that underpins this relationship. What can from here be said about the eros - and why can't it help but being a pedagogical eros? 
In a last twist, let's have a look at what eros as drive towards the atopos means, and we will see that we can lay aside all superficial distinctions between sexual love and pedagogical love for there is only one kind of real love, and that it is always pedagogical - leaving us to question whether all other sorts of eros are inferior as they are always based upon mere appropriation and usage of the other.

What is it about the atopos that attracts Alcibiades? In a somewhat surprising twist, it could be said that it is exactly the incomparableness of the atopos that is attractive: Not being identifiable and resistant to all known categories, the atopos rips the other person out of its usual state of being into what has always been described as ec-stasis, as standing besides oneself. This specific state is pleasing and fearful at the same time - being in ec-stasis means to experience a higher degree of awareness of oneself by distancing oneself from the usual ways of being. This is what lies at the heart of the pedagogical eros in both the teacher and the student - even though the reason for the ec-stasis is a very different one on both sides: The teacher is attracted to the emptiness of the student and the infinite potentiality of the future; the student is attracted to the completeness of the teacher and the infinite actuality of the past; and it is the moment that is the present in which past and future meet and the new future begins to unfold on the foundations of the past - a process of meeting and unfolding that is called education and that is governed by this erotic attraction of the atopos. As has already been remembered above: In Plato, the ultimate goal of education is the comprehension of the idea of the good, that is: the idea of ideas something that not even the teacher has actually achieved when entering the relationship. The ultimate aim is utterly incomprehensible to both of them - and this might be the third relation of atopos here: teacher and student are attracted to each other as atopoi for each other, and together they are drawn to the great atopos of the idea of the good, connected in their desire to relate to the seemingly incomprehensible, to something that can only be vaguely prefigured at the beginning of the pedagogical adventure. Or, in yet other words: What constitutes the pedagogical triangle in the first place is the state of being an atopos for each other - the teacher for the student, the student for the teacher, and the idea of the good for both, student and teacher; and it is a pedagogical relation because the person recognized and acting as teacher (Socrates) engages with the student's (Alcibiades') relation to the atopos (Idea of the Good) in order to support changing it for the better, i.e. improving it. 


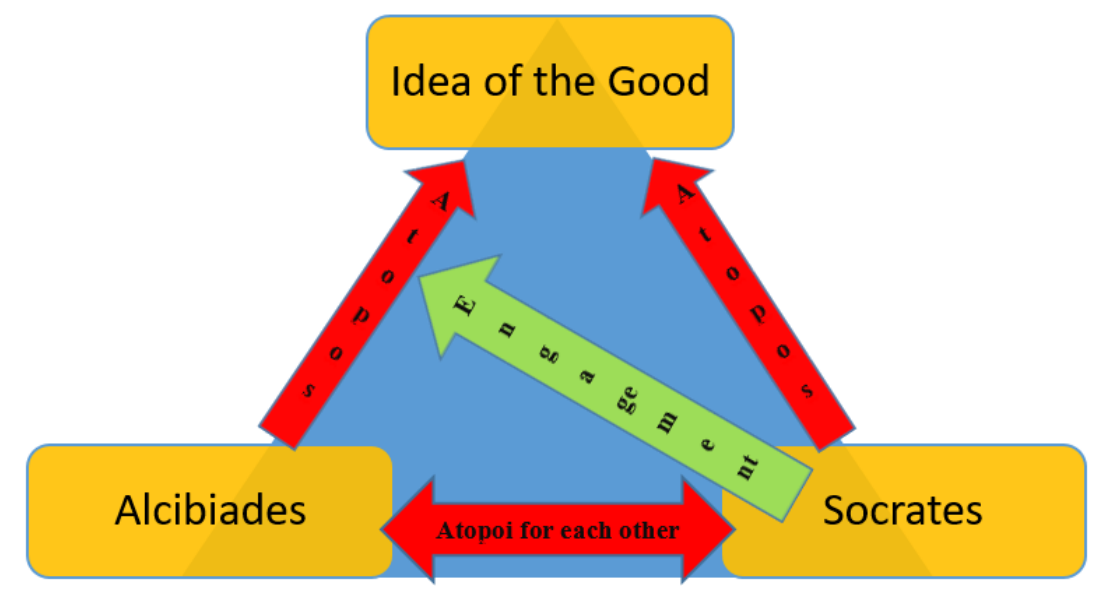

\section{Eroticism, or The Gift of Transformation}

Why was Plato's concept of Pedagogical Eros attractive to the progressive educators? Because it denies that education is solely about a predetermining positivity - a positivity where the teacher attempts to form the student in his own image and the student attempts to copy the teacher (as can be seen in the teaching of simple skills like writing or in more complex endeavours like in moral education where the learner is encouraged to follow the example the teachers is expected to present). This relation, which might be the most common when people nowadays talk about education, was and still is un-erotic. In this relation - and it doesn't matter if we talk about pedagogy or sexuality - one only uses the other as a means to an end of identification, of becoming identical, and it is not the ec-stasis producing, undetermined negativity but the consolidation producing positivity that forms the basis of such a relation. Here the student is only interested in the teacher inasmuch as the teacher represents something specific (a capacity, for example, that the student aspires to learn), and the teacher is interested in the student only as he or she can form the student in his own image (that is: teaching as transmission). Here both only consume each other and submit to an idea of a measurable education that views the relation as being successful in the light of a pre-given image of the goal of the change. To the same degree to which the teacher wants to form the student according to a pre-given image s_he degrades her/himself to an assistant of the student's appropriation, whereas the student agrees to submit to the mastery of the teacher. We can call this pornography - sexuality of appropriation - or common education: Both are founded upon a perversion of the original eros which is, so to speak, an eros of constant death and re- 
formation and not an eros of life as conservation; and it is because of this that the real eros is always pedagogical as he always will achieve a deeper transformation - or, to speak with Bataille: The real eros is always an Eros of Transgression (Bataille, 1986; 1989). The arrow of the pedagogical eros strikes completely unexpectedly - we never know when it hits, and we certainly cannot plan for it to hit: As every love, it is nothing but kairos - a moment of unexpected (and maybe even undeserved) luck, and what then happens, founded upon pedagogical eros, is again neither planned nor justifiable but remains somewhat surprising and unfinished, and it is only the inferior concept of positive education that pretends to be able to justify what happens (as if a final justification could be given for the aims and goals we aspire to in this positive education $\left.{ }^{20}\right)$. In the end, it is trust in the face of the utterly unknown that governs a relation of real eros, and not the lie of rational explanations and procedures: The studentlover trusts in the teacher-lover as being not manipulative and abusive; the teacher-lover trusts in the student-lover inasmuch as she hopes that whatever transformation he is undergoing, it will be somehow beneficial to both, teacher and student. True eros accepts the risk of the unknown - or, in other words: in education and sexuality alike, only if it is based upon real eros is freedom preserved on both sides, for the lover-teacher and the lover-student, where the student doesn't chain herself to the aims and goals represented by the teacher (which would merely repeat the old and not develop something new), and where the teacher doesn't degrade herself to being a mere means to someone else's ends.

Passionate pedagogy in any setting is likely to spark erotic energy. It cannot be policed or outlawed. This erotic energy can be used in constructive ways both in individual relationships and in the classroom setting. (hooks, 1996: 50) And maybe the distinction of sexuality and education with regard to the attraction that binds people together is only relevant where the false eros - the eros of appropriation - forms the basis of the relation: education and pornography might be distinguished by the first being understood as an appropriation of the mind, whereas the second one could be regarded as an appropriation of the body. True eros in education or sexuality might be just one: it is, according to Marsilio Ficino, the power that transforms (Ficino, 1985; see also: Hampton, 2004) - a chimera of negativity and positivity, where negativity somehow leads to a former unknown new positivity and not to a mere identification with and repetition of the old. And maybe all this is not education anymore as it is free of intentionality to an extent to 
which education cannot be: What transforms us the most is never planned or imagined - it might be hoped for, one might prepare oneself for its arrival in some way. But in the end, real love remains an unexpected gift to be accepted in humility.

\section{$\underline{\text { Notes }}$}

1. However, it has to be noted that despite the fact that Biesta aspires to give a systematic account of the possible purposes of education, his concept of 'subjectification' is a very specific one one that is valid only in a certain type of modern society (and it might be open to discussion which modern state actually embraces this concept in its institutionalized education). A somewhat more neutral way of formulating the concept of 'subjectification' - of 'becoming a subject' - would need to refrain from a specific idea of subject to be developed through education as purpose, and would need to connect to a broader (maybe dialectical) distinction between the more socially oriented and the more individually oriented side of the subject that is to be developed through education. In other words: education relates to the relation one has to oneself and to the relations one entertains to others; and it cannot be part of a systematic description of education to inscribe a specific idea of how this relations should look like (leaving open the possibility to refer to certain kinds of education as not being congruent with our ideas of what education should achieve but being education nevertheless).

2. A logic that is unmasked by the widely accepted design of numerous ITE programs which require a completed course and degree in a specific discipline (biology, geography, English etc.) before adding an extension in general and specific pedagogy (or Education Studies and Curriculum Studies) - and where the studying of the disciplines may take up the period of a complete Bachelor's Degree whereas the whole pedagogical program as an almost dispensable appendix lasts just about one year (including placements).

3. According to Kyriacou et al. (1999), personal reasons to become a teacher vary with regard to different countries and contexts.

4. It should be noted, that the notion of 'education' as it is used here, does not only refer to practices of so-called 'formal' education, but to all practices where the initiation and guidance 
of learning and/ or transformation aims at the change of a person - a change that is regarded as 'improvement'.

5. The actual quote is as follows: "School is the advertising agency which makes you believe you need the society as it is." (Illich, 1971: 163)

6. The term 'recognizing' is chosen deliberately as it embraces epistemological aspects (someone is recognized by someone as someone specific - e.g. as representative of a specific kind) as well as affective aspects (someone is affirmed by someone in his specific way of being - e.g. in her/his enacting of a role).

7. Which is exactly the reason why History of Education as well as an Intercultural Comparative Education that dares to hermeneutically engage with the Other (rather than turning it into a statistics like e.g. in school assessment studies like PISA) must not disappear from an Education Studies curriculum.

8. E.g. Paul de Lagarde.

9. Especially associated with the works of Wilhelm Dilthey and Henri Bergson.

10. For the English context, Cecil Reddie and his school in Abbotsholme might provide a striking example for the translation of the doctrines of the Life Reform Movement into pedagogical practice (Reddie, 1900).

11. 'Child-centredness' may be a central notion of all progressive education that draws its tradition back to Rousseau (mediated through e.g. Ellen Key's seminal work Barnets århundrade (1900), that was rapidly translated into several other languages; however, the English translation The Century of the Child didn't see the light of day before 1909). But it has to be remembered that the notion of 'child-centredness' is nothing less than clear: a wide range of diverse meanings are associated with this term (Chung/ Walsh, 2000).

12. Progressive education at the beginning of the 20th century wasn't of course a purely German movement: It was indeed international and included pedagogues all over the world.

13. By, for example, Plotinus, Proclus, Philo of Alexandria, Origen of Alexandria, Methodius of Olympos, Augustine, Pseudo-Dionysius, Marsilio Ficino, Baldassare Castiglione, Pietro Bembo, Judah Leon Abravanel, Girolamo Benivieni, Margaret of Navarre, Honoré d'Urfé, 
Madeleine de Scudéry, Fénelon, Henry More, Anthony Ashley-Cooper (3rd Earl of Shaftesbury), Friedrich Hölderlin, and many others.

14. In general, there is a peculiar renaissance of the notion of 'Eros' in this era: All of a sudden, everybody was talking about the eros. As to why this happened, remains to be investigated. In general, the praise for Classic Greek culture has been a long-standing tradition in Germany throughout the 18th and 19th century, based on the works of J. J. Winckelmann, and it was the pedagogue Eduard Spranger who in 1921 coined the term 'Third Humanism' for this cultural tradition (Spranger, 1922), and who himself contributed to the widespread discussions around the pedagogical eros (Spranger, 1921/22).

15. The history of this difficulty was by no means restricted to the beginning of the 20th century: The German Progressive Education movement received an almost fatal blow when it became public in 1998 that one of the flagship-schools of Progressive Education - the Odenwaldschule (est. 1910) - was the site of an abhorrent series of child-/ student-abuses committed by teachers in the $1970 \mathrm{~s} / 80$ s. Even though it was not the only boarding school that was shaken by this kind of disclosure (several Christian gymnasiums were at the same time revealed to have been places of constant abuse), it was especially the concept of the progressive Pedagogical Eros that became discredited - a concept thought to suggest an unhealthy close relationship of teacher and student. And so much is this concept linked with the whole Progressive Education movement in Germany that its downfall resulted in the almost complete renunciation of the German Progressive Education (at least in public statements). However: The whole situation is of course much more complicated as the battle between 'Progressive Education' and 'Traditional Education' has always been part of the political landscape and its ideological battles in Germany, and not every projectile shot in this war is of educational nature.

16. Another dimension that needs further discussion is the personal interest that at least some of the pedagogues take in those debates: It is interesting to note how many of the proponents of pedagogical eros were involved in contemporary discussions around what has been framed as 'homosexuality' in this period (Oelkers, 2011).

17. Especially Socrates has always been described as someone decidedly not beautiful. 
18. Protagoras 361a-b, Theaetetus 149a, Phaedrus 230c-d. However, one has to be cautious in drawing parallels between different Platonic dialogues as if the author had always been consistent in his writing through the years (which is clearly not the case).

19. This emphasis on 'atopos' as the defining feature of eros is hugely inspired by Byung-chul Han's The Agony of Eros (Han, 2017).

20. It should be remembered that in the end, normative deliberations remain completely unfounded and therefore always contestable.

\section{$\underline{\text { References }}$}

Bataille, G. (1986). Erotism: Death and Sensuality, trans. M. Dalwood. San Francisco: City Lights Books.

Bataille, G. (1989). Tears of Eros, trans. P. Connor. San Francisco: City Lights Books.

Biesta, G. (2009). Good education in an age of measurement: On the need to reconnect to the question of purpose in education. Educational Assessment, Evaluation and Accountability, 21(1), pp. $33-46$.

Chung, S., and Walsh, D. J. (2000). Unpacking child-centredness: A history of meanings. Journal of Curriculum Studies, 32(2), pp. 215-234.

Dover, K. J. (2016). Greek Homosexuality. $3^{\text {rd }}$ ed. Cambridge/ MA: Harvard University Press

Ficino, M. (1985). Commentary on Plato's Symposium on Love (De Amore, Commentarium in convivium Platonis, 1469/ 1475), translated by Sears Jayne. Dallas, Texas: Spring Publications.

Friesen, N. (2017). The pedagogical relation past and present: experience, subjectivity and failure. Journal of Curriculum Studies, 49(6), pp. 743-756.

Geuter, U. (1994). Homosexualitat in der deutschen Jugendbewegung: Jungenfreundschaft und Sexualitat im Diskurs von Jugendbewegung, Psychoanalyse und Jugendpsychologie am Beginn des 20. Jahrhunderts. Frankfurt/M.: Suhrkamp.

Han, B.-C. (2017). The Agony of Eros. Cambridge/MA: MIT Press.

Hampton, T. (2004). Strange Alteration: Physiology and Psychology from Galen to Rabelais. In: G. K. Paster, and K. Rowe, and M. Floyd-Wilson, eds., Reading the Early Modern Passions: Essays in the Cultural History of Emotion, $1^{\text {st }}$ ed. Philadelphia: University of Pennsylvania Press, pp. 272-93.

hooks, b. (1996). Passionate Pedagogy; erotic student/faculty relationships. Z Magazine, March, pp. 4551. 
Illich, I. (1971). Deschooling society. New York: Harper \& Row.

Key, E. (1900). Barnets århundrade. Stockholm: Bonnier (English: The Century of the Child, 1909, New York \& London: G.P. Putnam's Sons).

Kyriacou, C., and Hultgren, Å., and Stephens, P.(1999). Student teachers' motivation to become a secondary school teacher in England and Norway. Teacher Development, 3(3), pp. 373-381.

Levinas, E. (1987). Time and the Other. Pittsburgh: Duquesne University Press.

Nietzsche, F. (1872). Ueber die Zukunft unserer Bildungsanstalten. Sechs öffentliche Vorträge In: F. Nietzsche (1999). Sämtliche Werke. Kritische Studienausgabe in 15 Einzelbänden, Vol. 1, ed. by Giorgio Colli \& Mazzino Montinari. $3^{\text {rd }}$ ed. München/ Berlin/ New York: De Gruyter, pp. 641-752. (English: Nietzsche, F. (2016): Anti-Education: On the Future of Our Educational Institutions. New York: New York Review Books).

Nietzsche, F. (1874). Unzeitgemässe Betrachtungen. Zweites Stück: Vom Nutzen und Nachtheil der Historie für das Leben. In: F. Nietzsche (1999). Sämtliche Werke. Kritische Studienausgabe in 15 Einzelbänden, Vol. 1, ed. by Giorgio Colli \& Mazzino Montinari. $3^{\text {rd }}$ ed. München/ Berlin/New York: De Gruyter, pp. 243-334. (English: Nietzsche, F. (1980). On the Advantage and Disadvantage of History for Life. Cambridge/MA: Hackett Pub Co).

Nohl, H., and Pallat, L. (eds.) (1933). Handbuch der Pädagogik. Bad Langensalza: Julius Beltz Verlag. Oelkers, J. (2011). Eros und Herrschaft: Die dunklen Seiten der Reformpädagogik. Weinheim: Beltz. Plato (1925). Plato in Twelve Volumes, Vol. 9, translated by Harold N. Fowler. Cambridge/ MA: Harvard University Press.

Reddie, C. (1900). Abbotsholme 1889-1899. London: George Allan.

Spranger, E. (1921/22): Eros. Kunstwart und Kulturwart, 35(1), pp. 257-263.

Spranger, E. (1922). Der gegenwärtige Stand der Geisteswissenschaften und die Schule. Leipzig: Teubner.

Zeidler, K. (1920). Vom erzieherischen Eros. Lauenburg: Saal Zippel. 